\title{
ELK FOOD HABITS AND RANGE INTERACTIONS \\ WITH OTHER HERBIVORES IN WIND CAVE NATIONAL PARK
}

\author{
Adrian P. Wydeven \\ lowa Cooperative Wildife Research Unit \\ lowa State University
}

\section{Objectives}

The elk (Cervus elaphus nelsoni) population in Wind Cave National Park (WCNP) has varied considerably during the last 20 years (Lovaas 1973, Varland et al. 1978). Leopold et al. (1963) recommended that ungulates in national parks "be reduced to levels that the range will carry in good health and without impairment to the soil, the vegetation, or to habitats of other animals". Because elk are able to occupy a wide variety of habitats (Murie 1951), and have such varied diets (Kufeld 1973), they have great potential to compete with other herbivores. Data are needed on specific elk food habits and herbivore habitat relationships in WCNP to adequately manage ungulate populations. A description of WCNP was given by Lovaas (1973), and the previous report on the present study (Wydeven 1978). Field work was conducted from 6 June 1976 through 12 August 1977.

The specific objectives of this project were as follows: determine food habits of elk and patterns of range use; determine principal forage species and select methods for evaluating forage trends; investigate competition for forage among herbivores; and evaluate health of the elk population. Competition was examined mainly between the park ungulates, consisting of bison (Bison bison), pronghorn (Antilocapra americana), mule deer (Odocoileus hemionus), and elk.

\section{Procedure}

Major field procedures included collection and postmortem examinations on 30 elk, feeding-site examinations, kill-site examinations, seasonal forage availability analysis, and ungulate observations (Wydeven 1978). Rumen samples were examined by a point-analysis method. Histopathological examinations were made on tissue samples by David L. Graham (Veterinary Pathology, lowa State University, Ames). A modified sugar centrifugationfloation technique was used to concentrate parasite eggs, larvae and oocysts in fecal samples. Serological examinations of elk blood samples were conducted by the National Animal Disease Center, USDA, Ames, Iowa. Elk were aged using cementum layer counts by Leslie Rice (South Dakota Department of Game, Fish and Parks, Rapid City). 
Statistical analysis of the data was done by SAS computer programs (Barr et al. 1976). Comparisons and relationships were tested using the following: chi-square, t-test, analysis of variance, linear regression, correlation coefficients, and $z$-tests. Significance levels for most tests included $0.01,0.05$, and 0.10 . Modifications for multiple comparisons were made on Z-tests (Neu et al. 1974). Similarity indices (SI) were calculated in the manner of Anthony and Smith (1977).

Results and Discussion

Winter was the only period during which food habits data were available for all ungulates. Elk and pronghorn were most similar ( $\mathrm{SI}=50$ percent) in forage selection at feeding sites; both species utilized sageworts (Artemisia spp.) extensively. Overlap between elk and bison was 30 percent while other combinations of species had SI values of 15 percent or less. Elk and bison fed on similar graminoids. Mule deer fed mostly on browse, while elk fed on forbs and graminoids.

Bison and pronghorn were most similar of all species in habitat selection ( $S I=81-95$ percent) and spatial distribution ( $S I=50-74$ percent). Habitat use of bison and pronghorn was approximately the same during summers (1976 and 1977) and spring $(P>0.10)$, but was different during fall and winter $(P<0.01)$. Elk and mule deer were the second most similar in habitat selection $(\bar{S} \mid=67-83$ percent), but were the most dissimilar in spatial distribution ( $S I=7-23$ percent). Other combinations of species were less than 70 percent similar in habitat selection, and 47 percent or less similar in spatial distribution. Bison and pronghorn generally favored silty range sites, while elk and mule deer favored shallow range sites and woodland sites.

Bison were the only ungulate to consistently select for recent prairie burns. Pronghorn selected against a burned area during summer $1977 \quad(p<0.05)$. Elk observations on burns were too infrequent to determine selection.

Pronghorn were sighted more frequently on prairie dog towns than any other ungulate. Generally ungulate use on prairie dog towns was highest in summer and lowest in winter. Elk use of prairie dog towns was highest in fall.

Males and mixed groups (females, juveniles, and others) of ungulates selected habitat differently among elk and bison, but similarly among pronghorn and mule deer. Elk male groups had very low spatial overlap with elk mixed groups ( $S I=9-29$ percent). Apparently elk and bison minimize intraspecific competition by differential habitat selection and by spatial segregation between sex groups.

The weight of bull elk was variable, but appeared to decline from summer through winter. Mean bull weight during winter was significantly lower than mean summer weight $(\underline{P}<0.05)$. Such weight changes are generally expected for Cervus elaphüs (Mitchell et al. 1976). 
Elk were mostly in good condition. Sarcocystis spp. were found in 23 of 24 elk hearts, but did not appear to seriously affect the elk. Hemosiderosis was found in 6 of 21 livers, probably related to age as 5 were over 6 years old. Chronic interstitial pneumonia was found in 3 of 25 lungs.

Two elk were positive for anaplasmosis and three for brucellosis out of 25 serum samples. No elk was found positive for bovine viral diarrhea, infectious bovine rhinotracheitis, parainfluenza, bluetongue, epizootic hemorrhagic disease, or 12 serotypes of leptospirosis.

\section{Recommendations and/or Conclusions}

Competition among ungulates is generally minimized by differential habitat selection, spatial distribution, and forage selection. Elk and pronghorn have the greatest potential for winter forage competition. Elk may have displaced mule deer, as they both have similar habitat selection, but differ greatly in spatial distribution. Prairie dog towns are utilized to some extent by all ungulates. Further studies are needed to determine elk selection for burned areas. Pathological and physiological conditions studied did not seem to be important to the health of the elk population.

\section{Acknowledgments}

This study was supported by the National Park Service through the lowa Cooperative Wildlife Research Unit (U.S. Fish and Wildlife Service, lowa Conservation Commission, lowa State University, and The Wildlife Management Institute, cooperating). Helpful advice and support in the field was received from Robert B. Dahlgren, Unit Leader; Richard W. Klukas, Wildlife Biologist, WCNP; and Allan L. Lovaas, National Park Service. Other WCNP personnel were helpful, namely Lester F. McClanahan, Dean Shilts, Dale Smith, and Robert M. Andrew. Keith E. Severson, U.S. Forest Service; Ralph S. Cole, U.S. Soil Conservation Service and F. Robert Gartner, South Dakota State University, gave valuable assistance, as did personnel of Custer State Park and the South Dakota Department of Game, Fish and Parks. This study is Project No. 2181 of the lowa State University Agriculture and Home Economics Experiment Station.

\section{Literature Cited}

Anthony, R. G. and N. S. Smith. 1977. Ecological relationships between mule deer and white-tailed deer in southeastern Arizona. Ecol. Monogr. 47: 255-277.

Barr, A. J., J. H. Goodnight, J. P. Sall and J. T. Helwigh 1976. The user's guide to SAS 76. SAS Institute Inc. Raleigh, North Carolina. 329pp.

Kufeld, R. C. 1973. Foods eaten by the Rocky Mountain elk. J. Range Manage. 26(2): 106-113. 
Leopold, A. S., S. A. Cain, C. M. Cottam, I. N. Gabrielson and T. L. Kimball. 1963. Wildlife Management in the national parks. Trans. N. Am. Wildl. Nat. Res. Conf. 28:29-42.

Lovaas, A. L. 1973. A cooperative elk trapping program in Wind Cave National Park. Wildl. Soc. Bull. I(2): 93-100.

Mitchell, B., D. McCowan and 1. A. Nicholson. 1976. Annual cycles of body weight and condition in Scottish red deer, Cervus elaphus. J. Zool., London 180: 107-127.

Murie, 0. J. 1951. The elk of North America. The Stackpole Co., Harrisburg, PA; The Wildlife Management Institute, Washington, DC. $376 p p$.

Neu, C. W., C. R. Byers and J. M. Peek. 1974. A technique for analysis of utilization-availability data. J. Wildl. Manage. 38(3): 541-545.

Varland, K. L., A. L. Lovaas and R. B. Dahlgren. 1978. Herd organization nad movements of elk in Wind Cave National Park, South Dakota. USDI, National Park Service, Natural Resources Report No. 13, 28 pp.

Wydeven, A. P. 1978. Elk food habits and range interactions with other herbivores in Wind Cave National Park, in First Annual Report, Univ. Wyo.-Nat l. Park Serv. Res Cent., 1977. 